\title{
Antifungal Activity and Qualitative Phytochemical Analysis of Some Medicinal Plants in Jaffna (Sri Lanka)
}

\author{
Tharmarajah Manoranjan ${ }^{1 *}$, Reeka Thangarajah' ${ }^{1}$, A. C. Thavaranjit ${ }^{2}$ \\ ${ }^{1}$ Department of Chemistry, University of Jaffna, Jaffna, Sri Lanka \\ ${ }^{2}$ Department of Botany, University of Jaffna, Jaffna, Sri Lanka \\ Email: `tmranjan@jfn.ac.lk, tmranjan@gmail.com, anujiranjit@gmail.com
}

How to cite this paper: Manoranjan, T., Thangarajah, R. and Thavaranjit, A.C. (2018) Antifungal Activity and Qualitative Phytochemical Analysis of Some Medicinal Plants in Jaffna (Sri Lanka). International Journal of Organic Chemistry, 8, 335-340. https://doi.org/10.4236/ijoc.2018.84025

Received: September 11, 2018

Accepted: October 22, 2018

Published: October 25, 2018

Copyright $\odot 2018$ by authors and Scientific Research Publishing Inc. This work is licensed under the Creative Commons Attribution International License (CC BY 4.0).

http://creativecommons.org/licenses/by/4.0/

\begin{abstract}
Many members of the Labiatae family are used in traditional and folk medicine and also used as culinary and ornamental plants. Leaves are the most used plants parts of this family. Ethanolic extract of the leaves, stem, seeds of Leucas zeylanica, Ocimum canum, Ocimum sanctum and leaves of Mentha arvensis, Ocimum basilicum were subjected to phytochemical screening and antifungal assays against Aspergillus sp., Penicillium sp., Trichoderma sp., Mucor sp., Rhizopus sp. was determined by using the agar streaking assay method after 48 and 72 hours of incubation. All parts of the plants were found to contain flavonoid/s and alkaloid/s except for the absence of alkaloids in seeds of $L$. zeylanica and stem of $O$. sanctum respectively. Tannins were present in all parts of plants such as $L$. zeylanica, $O$. canum, $M$. arvensis and absent in $O$. sanctum and $O$. basilicum. Phlobatannins were only present in leaves of $L$. zeylanica and saponins were present only in leaves of $O$. basilicum. The leaves of $L$. zeylanica, $O$. basilicum, $M$. arvensis, $O$. sanctum and seeds of $O$. sanctum and $O$. canum showed the presence of steroids. Terpenoids were present in all parts of $O$. sanctum and $O$. canum than the other plants. The cardiac glycosides were present in all parts of $O$. sanctum than the other plants tested. Leaves of $O$. sanctum and $M$. arvensis exhibited strong positive antifungal activity against Aspergillus sp. Leaves of $O$. canum, O. basilicum and M. arvensis and stem of $O$. canum showed strong positive activity against Mucor sp. L. zeylanica only exhibited the antifungal activity against Mucor sp. Penicillium sp. was inhibited by the leaves and seeds extracts of $O$. sanctum. Degree of activity was low in L. zeylanica compared with other plant extracts. Most of these plant parts did not show any activity against Trichoderma sp. and Rhizopus sp. This study revealed that the antifungal activity of leaves of these plants was high than other plant parts against tested fungi.
\end{abstract}




\section{Keywords}

Leucas zeylanica, Ocimum canum, Ocimum sanctum, Mentha arvensis, Ocimum basilicum, Antifungal Activity

\section{Introduction}

Many medicinal plants are a source of great economic value all over the world. Nature has bestowed on us a very rich botanical wealth and a large number of diverse type of plants grow in different parts of the country [1]. The Labiatae family (Lamiaceae) is one of the largest and most distinctive families of flowering plants. In Sri Lanka, there are 63 species belonging to 12 genera of these 51 are indigenous and 12 being endemic [2]. Leucas zeylanica (muditumpai-T; geta-thumba-S), Ocimum canum (ganjankorai-T; heentala-S), Ocimum sanctum (karunthulasi-T; madurutala-S), Ocimum basilicum (tirnutpachi-T; suwanda-tala-S) and Mentha arvensis (pudina-T; odutalan-S), are used in herbal medicine in Sri Lanka and other countries. Bioactive compounds with antimicrobial activity play an important role in herbal medicine. Objective of this study is the extraction of different plant parts in ethanol, identifying the phytochemicals qualitatively and screening for their antifungal activity.

\section{Materials and Methods}

The whole plant of L. zeylanica, $O$. canum, and $O$. sanctum were collected from uncultivated farmlands located at meesalai (chavakachcheri), Jaffna in the Northern Province of Sri Lanka. O. basilicum and $M$. arvensis were collected from farmlands at Thirunelvely (Jaffna) in the Northern Province of Sri Lanka. The taxonomic identities of these plants were confirmed by using herbarium samples preserved in the department of Botany, University of Jaffna.

\subsection{Method of Extraction of Plant Materials}

The plant materials were air dried and these samples were ground into uniform powder with electric blender. $100 \mathrm{~g}$ of each ground samples were taken into a container separately and adequate amount of ethanol was added to an each container with occasional shacking. Each extract was filtered after 24 hours period. This procedure was repeated and both filtrates were combined. The solvent was evaporated by using rotatory evaporator and the weights were recorded.

\subsection{Phytochemical Screening Tests for Ethanol Extract}

The phytochemical tests have carried out on the crude of the ethanol extract $(0.2 \mathrm{~g})$ using standard phytochemical procedures [3]. The compounds interests are alkaloids, saponins, terpenoids, steroids, flavanoids, tannins, phlobatannins, and cardiac glycosides.

Test for alkaloids: A few drops of Wagner's reagent were added to the crude 
$(0.2 \mathrm{~g})$ of the sample along the wall of the test tube.

Test for tannins: $0.2 \mathrm{~g}$ of crude of the sample was boiled with $20 \mathrm{ml}$ of distilled water and it was filtered. Then few drops of $0.1 \% \mathrm{FeCl}_{3}$ were added.

Test for phlobatannins: $0.2 \mathrm{~g}$ of crude of the sample was boiled with $1 \%$ aqueous hydrochloric acid.

Test for saponins: $0.2 \mathrm{~g}$ of crude of the sample was boiled with $20 \mathrm{ml}$ of distilled water in a water bath and it was filtered. Then filtrate was mixed with $5 \mathrm{ml}$ of distilled water and it was shaken vigorously for a stable persistent froth.

Test for flavonoids: $0.2 \mathrm{~g}$ of crude of the sample was heated with $10 \mathrm{ml}$ of ethylacetate over a steam bath for 3 minutes. The filtrate was shacked with $1 \mathrm{ml}$ of dil $\mathrm{NH}_{3}$ solution.

Test for steroids: $2 \mathrm{ml}$ of acetic anhydride to $0.2 \mathrm{~g}$ of crude sample with $2 \mathrm{ml}$ of con $\mathrm{H}_{2} \mathrm{SO}_{4}$ were added.

Test for terpenoids: $3 \mathrm{ml}$ of con $\mathrm{H}_{2} \mathrm{SO}_{4}$ was added carefully to the mixture of 5 $\mathrm{ml}$ of extract and $2 \mathrm{ml}$ of $\mathrm{CHCl}_{3}$.

Test for cardiac glycosides: Treat $0.2 \mathrm{~g}$ of crude with $2 \mathrm{ml}$ of glacial acetic acid which contains one drop of $\mathrm{FeCl}_{3}$ solution and this underplay with $1 \mathrm{ml}$ of con $\mathrm{H}_{2} \mathrm{SO}_{4}$.

\subsection{Anti Fungal Activity Assay for the Ethanol Extracts}

All plants extracts were tested for their antifungal activity against different fungi such as Pencillium sp., Aspergillus sp., Rhizopus sp., Mucor sp. and Trichoderma sp. Antifungal activity of the extracts was determined by using the agar streaking assay method [4]. The extracts of L. zeylanica (seeds, stem and leaves) were streaked on Potato Dextrose Agar (PDA) in the Petridish at equal distance among them. A fungal disc ( $5 \mathrm{~mm}$ ) (Penicillium sp.) was taken with the help of sterile cork borer and it was placed on the centre of above PDA medium. The antifungal activity was determined in terms of inhibition/antagonism (strong positive, weak positive and no activity) after 48 hours, 72 hours of incubation periods. All these test plates were compared with control plate. The above procedure was repeated to fungi such as Aspergillus sp., Mucor sp., Trichoderma sp. and Rhizopus sp. and other plants.

\section{Results and Discussion}

The phytochemical analysis of five medicinal plants is summarized in Table 1. Phytochemical screening tests of the plants such as L. zeylanica, $O$. canum, $O$. sanctum, $O$. basilicum and $M$. arvensis showed that the flavanoids were the common constituents. L. zeylanica and $O$. canum contained tannins in the stem and leaves except seeds. Alkaloids were found in leaves, stem of L. zeylanica and absent in seeds. Similarly alkaloids were transparently seen in all plant parts of $O$. canum. But the leaves of L. zeylanica, O. canum, O. sanctum, O. basilicum and $m$. arvensis also showed the presence of alkaloids. Saponins and phlobatannins were only found in leaves of the $O$. basilicum, L. zeylanica respectively and 
absence in other parts of these plants. The extract from leaves of all plants exhibited the presence of steroids except $O$. canum. All plant parts of $O$. sanctum, leaves and seeds of $O$. canum and leaves of $O$. basilicum and $L$. zeylanica showed the presence of cardiac glycosides. Flavanoids and terpenoids were found in leaves, stem and seeds of the $O$. sanctum and $O$. canum. The presence of alkaloids in $O$. sanctum has been reported by the researchers and this plant widely used in herbal medicine [5].

The crude extracts from seeds and leaves of $O$. sanctum exhibited significant antifungal activity on most of the tested fungi. The degree of inhibition varied among fungi. Only seeds and stem of $L$. zeylanica showed positive activity against Mucor sp. after 48 hours and weak positive after 72 hours. This plant didn't show any activity against Aspergillus sp., Penicillium sp., Rhizopus sp. and Trichoderma sp. after 48 and 72 hours (Table 2).

Table 1. Phytochemical analysis of different plants parts.

\begin{tabular}{|c|c|c|c|c|c|c|c|c|c|c|c|}
\hline \multirow{2}{*}{ Plants } & \multicolumn{3}{|c|}{ L. zeylanica } & \multicolumn{3}{|c|}{ O. canum } & \multicolumn{3}{|c|}{ O. sanctum } & \multirow{2}{*}{$\begin{array}{c}\text { O. basilicum } \\
\text { Leaves }\end{array}$} & \multirow{2}{*}{$\begin{array}{c}\text { M. arvensis } \\
\text { Leaves }\end{array}$} \\
\hline & Seeds & Leaves & Stem & Seeds & Leaves & Stem & Seeds & Leaves & Stem & & \\
\hline Tannins & - & + & + & + & + & + & - & - & - & + & - \\
\hline Phlobatannins & - & + & - & - & - & - & - & - & - & - & - \\
\hline Alkaloids & - & + & + & + & + & + & + & + & - & + & + \\
\hline Saponins & - & - & - & - & - & - & - & - & - & + & - \\
\hline Flavonoids & + & + & + & + & + & + & + & + & + & + & + \\
\hline Steroids & - & + & - & + & - & - & + & + & - & + & + \\
\hline Terpenoids & - & + & - & + & + & + & + & + & + & - & - \\
\hline Cardiac glycosides & - & + & - & - & + & + & + & + & + & + & - \\
\hline
\end{tabular}

Note: +presence of constituent; -absence of constituent.

Table 2. Effects of crude of plant extracts on the growth of fungi after 48 and 72 hours.

\begin{tabular}{|c|c|c|c|c|c|c|c|c|c|c|c|c|c|c|c|c|c|c|c|c|c|c|}
\hline \multirow{3}{*}{$\begin{array}{c}\text { Micro } \\
\text { organisms }\end{array}$} & \multicolumn{6}{|c|}{ L. zeylanica } & \multicolumn{6}{|c|}{ O. canum } & \multicolumn{6}{|c|}{ O. sanctum } & \multirow{2}{*}{\multicolumn{2}{|c|}{$\begin{array}{c}O . \\
\text { basilicum } \\
\text { Leaves } \\
\text { (9) }\end{array}$}} & \multirow{2}{*}{\multicolumn{2}{|c|}{$\begin{array}{c}M . \\
\text { arvensis } \\
\text { Leaves } \\
(9)\end{array}$}} \\
\hline & \multicolumn{2}{|c|}{$\begin{array}{l}\text { Seeds } \\
(1)\end{array}$} & \multicolumn{2}{|c|}{$\begin{array}{c}\text { Stem } \\
(2)\end{array}$} & \multicolumn{2}{|c|}{$\begin{array}{l}\text { Leaves } \\
\text { (3) }\end{array}$} & \multicolumn{2}{|c|}{$\begin{array}{l}\text { Seeds } \\
(4)\end{array}$} & \multicolumn{2}{|c|}{$\begin{array}{l}\text { Stem } \\
(5)\end{array}$} & \multicolumn{2}{|c|}{$\begin{array}{c}\text { Leaves } \\
(6)\end{array}$} & \multicolumn{2}{|c|}{$\begin{array}{c}\text { Seeds } \\
(7)\end{array}$} & \multicolumn{2}{|c|}{$\begin{array}{l}\text { Leaves } \\
(8)\end{array}$} & \multicolumn{2}{|c|}{$\begin{array}{c}\text { Stem } \\
(9)\end{array}$} & & & & \\
\hline & 48 & 72 & 48 & 72 & 48 & 72 & 48 & 72 & 48 & 72 & 48 & 72 & 48 & 72 & 48 & 72 & 48 & 72 & 48 & 72 & 48 & 72 \\
\hline Aspergillus sp. & - & - & - & - & - & - & - & - & - & - & ++ & + & +++ & ++ & +++ & ++ & - & - & ++ & + & +++ & ++ \\
\hline Mucorsp. & ++ & + & ++ & + & - & - & + & - & +++ & + & +++ & ++ & ++ & + & - & - & ++ & - & +++ & + & +++ & + \\
\hline Penicillium sp. & - & - & - & - & - & - & - & - & - & - & - & - & +++ & ++ & +++ & ++ & + & - & +++ & ++ & +++ & ++ \\
\hline Trichoderma sp. & - & - & - & - & - & - & - & - & - & - & + & - & + & - & ++ & - & - & - & - & - & + & - \\
\hline Rhizopus sp. & - & - & - & - & - & - & - & - & - & - & ++ & + & - & - & ++ & + & - & - & - & - & - & - \\
\hline
\end{tabular}

+++ strong positive activity, ++ positive activity, + weak positive activity and -no activity. 
Leaves of $O$. canum showed strong positive activity against Mucor sp. after 48 hours and positive activity after 72 hours. Stem and seeds extracts of this plant did not show any activity against other fungi. Seeds of $O$. canum exhibited less activity compared with leaves and stem. O. sanctum showed the highest inhibition and strong positive activity against Aspergillus sp., Penicillium sp. at 48, 72 hours except stem of $O$. sanctum. At the same time leaves of $O$. sanctum showed positive activity against Trichoderma sp. and Aspergillus sp.

Stem of L. zeylanica, $O$. canum and $O$. sanctum commonly showed antifungal activity against $M u c o r$ sp. Similarly, leaves of $O$. canum, O. sanctum, O. basilicum and $M$. arvensis commonly inhibited Aspergillus sp. except leaves of L. zeylanica. Leaves of $M$. arvensis, $O$. basilicum and $O$. canum showed strong positive activity against Mucor sp. Leaves, stem, seeds of L. zeylanica didn't show activity against Trichoderma sp. This was due to inheritance of fungi, type and the amount of antifungal compounds present in the plant extract to exhibit inhibition. Previous studies indicated that these plants leaves had antibacterial as well as antifungal activity especially against dermatophytic fungi [6] [7] [8] [9]. But the present study showed that not only leaves but other plant parts exhibited antifungal activity.

This study revealed that the extract of $O$. basilicum and $O$. sanctum and $M$. arvensis contained significant amount of antifungal compounds and most of these compounds were present in leaves than other parts of these plants.

\section{Conclusion}

The present study of medicinal plants in family Labiatae showed that distribution of phytochemicals such as alkaloids, terpenoids, steroids, flavanoids, tannins and cardiacglycosides were rich compared to the distribution of phlobatannins, and saponins. Degree of antifungal activity varied among plants as well as among plant parts. Growth of Aspergillus sp., Mucor sp. and Penicilium sp. were strongly inhibited by $O$. sanctum, $O$. basilicum and $M$. arvensis extracts while Trichoderma sp. and Rhizopus sp. growth was only inhibited by $O$. canum, $O$. sanctum. Antifungal compounds were rich in leaves than the other parts except L. zeylanica. Leaves of Labiatae family members except $L$. zeylanica could be used to treat fungal diseases in herbal medicine. Further studies could be carried out to purify these bioactive compounds.

\section{Conflicts of Interest}

The authors declare no conflicts of interest regarding the publication of this paper.

\section{References}

[1] Joshi, B., Lekhak, S. and Sharma, A. (2009) Antibacterial Property of Different Medicinal Plants: Ocimum sanctum, Cinnomomum zeylanicum, Xanthoxylum armatum and Origanum majorana. Kathmandu University Journal of Science, Engineering and Technology, 5, 143-150. 
[2] Dassanayake, M.D. and Fosberg, F.R. (1981) A Rivised Hand Book to the Flora of Ceylon. Amerind, New Dhelhi, 108-194.

[3] Kathirkamanathan, S., Manoranjan, T., Thavaranjit, A.C. and Jeyadevan, J.P. (2015) Screening for in Vitro Antifungal Activity and Qualitative Phytochemical Analysis of the Fruit Extract of Capparis zeylanica. Der Pharma Chemica, 7, 282-286.

[4] Kunle, A.A.A. and Ikumapayi, A. (2006) Antifungal Property and Phytochemical Screening of the Crude Extracts of Functumia elastica and Mallotus oppositifolius. West Indian Medical Journal, 55, 219-223.

[5] Ahmad, S.D. and Khaliq, F. (2002) Morpho-Molecular Variability and Heritability in Ocimum sanctum Genotypes from Northern Himalayan Region of Pakistan. Pakistan Journal of Biological Science, 5, 1084-1087.

[6] Balakumar, S., Rajan, S., Thirunalasundari, T. and Jeeva, S. (2011) Antifungal Activity of Ocimum sanctum Linn. (Lamiaceae) on Clinically Isolated Dermatophytic fungi. Asian Pacific Journal of Tropical Medicine, 4, 654-657. https://doi.org/10.1016/S1995-7645(11)60166-1

[7] Dwivedi, D., Khandelwai, G., Patidar, R.K. and Singh, V. (2012) Antimicrobial Activity of Mentha arvensis against Clinical Isolates of Human Cariogenic Pathogens-An In-Vitro Study. IJPSR, 3, 1355-1360.

[8] Nabrdalik, M. and Grata, K. (2016) Antibacterial Activity of Ocimum basilicum L. Essential Oil against Gram Negative Bacteria. Post Fitoter, 17, 80-86.

[9] Babu, A., Noor, M.S., Jaikumar, K., Anand, D. and Saravanan, P. (2016) In-Vitro Antifungal Activity of Leaf Extracts of Leucas aspera and Leucas zeylanica. IJPSR, 7, 752-756. 